as the pores are filled with the immersion oil, since the membrane has the same refractive index as the immersion oil. The specimen is now ready for inspection by microscope, using transmitted light.

Sigurd Funder

Marwell Hauge Farmasøytisk A/S,

Oslo.

Funder, S., and Johannessen, S., J. Gen. Microbiol., 17, 117 (1957).

\section{Pogonophora from the Atlantic}

IT is becoming clear that the distribution of the Pogonophora is less limited than was formerly supposed. In the past few years the area of known occurrence has been extended beyond the Pacific Ocean to the Arctic basin ${ }^{1}$, the Greenland Sea ${ }^{1}$ and the Skagerak ${ }^{2,3}$. We have now found some of these interesting animals on the continental slope to the south-west of the British Isles; they are the first to be recorded from the Atlantic Ocean proper.

Our specimens of Pogonophora were obtained on May 4, 1957, by R.V. Sarsia, at a single station just west of the Little Sole submarine promontory : position, lat. $48^{\circ} 28^{\prime} \mathrm{N}$., long. $10^{\circ} 04^{\prime} \mathrm{W}$.; depth, 700 fathoms by echo-sounding, with a relatively level profile; bottom deposit, mud containing a little fine sand and foraminiferan shells. A 20-min. haul of the dredge produced the following Pogonophora:

\begin{tabular}{|c|c|c|c|c|c|}
\hline & $\begin{array}{c}\text { Tube } \\
\text { Iength } \\
(\mathrm{cm} .)\end{array}$ & $\begin{array}{l}\text { Tube } \\
\text { width } \\
(\mathrm{mm} .)\end{array}$ & $\begin{array}{c}\text { Length of } \\
\text { animal } \\
\text { less tentacle } \\
\text { (cm.) }\end{array}$ & $\begin{array}{c}\text { Width of } \\
\text { animal } \\
(\mathrm{mm} .)\end{array}$ & $\begin{array}{l}\text { No. of } \\
\text { speci- } \\
\text { mens }\end{array}$ \\
\hline $\begin{array}{l}\text { Siboglinum } \\
\text { sp. } A \\
\text { sp. } B \\
\text { sp. } C\end{array}$ & $\begin{array}{l}\text { up to } 40 \\
\text { up to } 10 \\
\text { up to } 5\end{array}$ & $\begin{array}{l}0 \cdot \breve{3} \\
0 \cdot 12 \\
0 \cdot 14-7\end{array}$ & $\begin{array}{l}\text { up to } 13 \\
\text { up to } 3 \\
\text { up to } 2 \cdot 5\end{array}$ & $\begin{array}{l}0 \cdot 4 \\
0 \cdot 09 \\
0 \cdot 12-5\end{array}$ & $\begin{array}{r}15 \\
7 \\
3\end{array}$ \\
\hline
\end{tabular}

These species will be described in more detail elsewhere; $B$ and $C$ resemble the Skagerak species Siboglinum ekmani Jägersten.

A. J. SoUthward

E. C. Sodthward

The Laboratory,

Citadel Hill,

Plymouth.

April 17.

${ }^{1}$ Ivanov, A. W., Zool. Jb., Abt. 1, 85, 431 (1957).

2 Jägersten, G., Zool. Bidr. Uppsala, 31, 211 (1956).

${ }^{3}$ Kirkegaard, J. B., Nature, 181, 1086 (1958).

\section{Resistance to Flow in Vascular Beds}

THE concept of resistance to flow is widely used by physiologists and clinicians when inferring vessel behaviour from pressure and flow data. For a great number of years 'resistance to flow' has been defined by physiologists as the ratio of the pressure drop across a vessel system to the flow that results. As so defined, Burton" has pointed out that ". . . resistance to flow is strictly analogous to 'resistance' in electrical measurements, which is defined by Ohm's Law", and he believes that "resistance to flow remains a useful clarifying concept". The resistance unit most widely used is the peripheral resistance unit (p.r.u.), which is, according to Green", "equivalent to the ohm", and is defined as 1 p.r.u. $=1 \mathrm{~mm}$. mercury $/ 1 \mathrm{ml}$. per min.

However, the Ohm's law analogy provides reliable information regarding vessel behaviour (in the

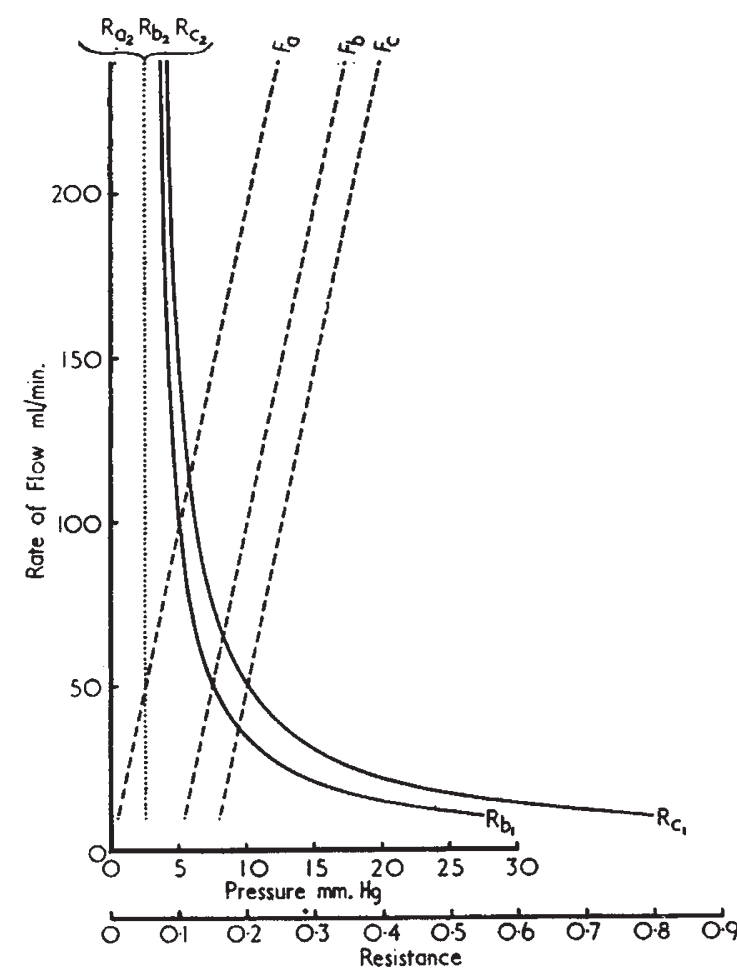

Fig. 1. Relations between: rate of flow and perfusion pressure (broken line); rate of flow and resistance to flow in peripheral resistance units (continuous line); rate of flow and resistance to
flow in dynamic resistance units (dotted line), in three different vessel systems

absence of turbulent flow and changes in viscosity of the perfusion fluid) only when the pressure-flow curve passes through the origin; in such conditions the resistance to flow may be expressed (in peripheral resistance units) as the reciprocal of the slope of the pressure-flow diagram at any given point.

Unfortunately, the pressure-flow curves of vascular beds rarely, if ever, pass through the origin, but usually exhibit a positive pressure intercept so that uncritical use of the Ohm's law analogy may be misleading.

Fig. 1 shows three pressure-flow diagrams: $F_{a}$ is the pressure-flow characteristic of a system in which the vessel walls are rigid; here resistance to flow may legitimately be expressed in peripheral resistance units as the reciprocal of the slope. $F_{b}$ and $F_{c}$ represent the pressure-flow relations in two vessel systems across which a positive pressure gradient must be established before flow commences; both $F_{b}$ and $F_{c}$ intercept the pressure axis at positive values. But since the slopes of $F_{a}, F_{b}$ and $F_{c}$ are identical, vessel resistance is the same in all three systems, and (since the pressure-flow curves are rectilinear) is independent of both pressure and rate of flow.

Fig. I also shows the relations between rate of flow and vessel resistance in the vascular systems $b$ and $c$, expressed (1) in peripheral resistance units by the Ohm's law analogy (continuous line) and (2) as the reciprocal of the slope of the pressure-flow diagram (dotted line). Resistance to flow expressed in peripheral resistance units as defined by Burton ${ }^{1}$ appears to be dependent upon rate of flow, although it is clear from the rectilinear pressure-flow diagrams 